$\xi=-1$

\title{
Will the Thai ABC Car Owners, Buy a Smart ABC Car? a Case Study in Bangkok Metropolis
}

\author{
Keerati Sittichainarong ${ }^{1 *}$, Aaron Loh $^{1}$, Preecha Methavasaraphak ${ }^{1}$, John Barnes ${ }^{1}$ \\ ${ }^{1}$ Assumption University of Thailand \\ *Corresponding author E-mail: nutsorayut@gmail.com
}

\begin{abstract}
Thailand is the biggest manufacturer of trucks and cars outside of Japan and China in Asia. Many had reported that "smart" technology especially that which leads towards driverless or autonomous vehicles will be the most important single development that will affect the automobile industry both domestically and globally. Hence this research is therefore on the readiness of Thai car owners to adopt the new technology and the intention to purchase a smart car in the near future. Specifically, it is a case study on the influential factors affecting the intent to purchase a smart car by owners of a top Japanese brand in Bangkok. A questionnaire survey was conducted on 385 existing car owners of the Japanese brand under consideration in metropolitan areas of Bangkok and the data returned analyzed by multiple linear regression. The outcome of the research pointed towards 'Self-identity" and 'Emotional connection' as the most influential factors towards the intent to purchase a smart car.
\end{abstract}

Keywords: Smart Cars; Autonomous Cars; Self-Driving Cars; Driver less Cars.

\section{Introduction}

Smart Cars, Autonomous Cars, Self-Driving Cars and Driver less Cars are the automobiles that have cutting edge functions such as self-driving and have the ability to drive itself without any control by the driver [1].

When we take a close look at the road accident statistics globally, more than 1.25 million people lose their life from road accident every year [2]. In Thailand alone, more than 19,000 people lose their life yearly. This high number lead Thailand to be the world's second largest number of people's death from road accident [3]. Meanwhile, [4] has proposed that smart cars technologies can reduce the road accident by $90 \%$ which it will save millions lives of people worldwide.

In terms of the contribution of automotive sectors toward Thailand's economy. Thailand is the world's sixth largest automotive manufacturer by producing more than one million automobiles which represents $12 \%$ of the country's GDP [5]. This is because to produce one car it is requires more than 30,000 parts [6]. Therefore, the supply chain of automobiles creates tremendous employment and great contribution to the microeconomy and macroeconomy of Thailand.

Currently, in Thai Automotive Market. There are more than 60 brands of cars of which $75 \%$ of market share are made by Japanese automotive manufacturers. Furthermore, [4] mentioned that, in the year 2050 the smart car will be "The primary means of transport." As a consequence, Smart Car technologies will play an important role in the future of automotive sector of Thailand.

\section{Literature Review}

Attributes: are the character, quality as well as features of the products [7]. For the automotive industry, the attributes of the cars are its design and its characters that are different from its competitors, the quality of the material built and the other functions that are equipped with the cars such as safety functions, technological functions. [8] have proposed that different people have different preference, needs and wants. So, the firm should know their points of parity and points of difference based on the attributes of the products. Successfully delivering what the customer wants and needs will shape the competitive advantage and will drive the sales of product, enhance repurchase and brand loyalty. Such points of difference may create the competitive advantage for the brand that competitors cannot perform or features that competitors cannot easily match, [9]. The previous research of [10] on high involvement and low involvement products stated that the automobile which is a high involvement product because when the customer has some purchase decision upon the choice of the cars brand and models, they select cars that have function, quality, and design, features that match their taste, perception and lifestyle. The automobile manufacturer that had created such products which integrate function which match customer expectation, can increase customer awareness. Automotive brands can convey symbolic statement which customer can be seen easily perceive. Moreover, [10] also mentioned that the well-known brand automaker can create a life-like style of its car appealing to personalities of the owners. [11] state that to understand the competitive forces, it is important that the marketers should understand the hierarchy of attributes that affect customer purchasing decision process. By understanding the factors that affect the decisionmaking process as well as the product attribute preferred by the customer. The company can persuade the customer and facilitate the customer decision-making process brand preference.

- Emotional Connection: Since the response of consumers is not always cognitive and logical the influential role of emotion in consumer behavior states that emotion plays a vital role in the decision-making process, because it creates a preference which leads to the decision making. Thus, when customers are evaluating 
brands, most people use emotion such as one's own experience and personal feelings as a substitute for facts or features. Some customer response comes from emotional rather than logical feeling. For example, happy, sad, accomplishment, excitement can play a decisive role a result, when the company successfully creates those feelings and delivers them to the customer, it can persuade the customer and lead to a purchase decision, [12]. In these terms, the company or brands may create the feeling in order to initiate the emotion that they want their customers to feel such as feeling of, importance, pride, confidence as well as excitement Many well-known brands use these techniques to create such feelings to in their customers [11]. Emotional significant appeals have increased among marketers of various automotive brands, on practical and impartial side of the brand in creating feelings of nostalgia. The brand that has been equipped with the emotional stories encourages people to pass their story of the brand to other people by word of mouth and other forms of sharing [13]. Moreover, emotional connection sometimes has a big impact on purchase decision, in some cases emotion have more power than cognitive thinking process of customers.

Brand Image: "Brand" is a name, design, symbol, sign, term [14] these attributes can be used to describe the brand separately or can be used as a combination. The intention of using the brand is to describe and differentiate one company and its competitors or it products or services. Towards the customer, the role of brand is to deliver the positive experience that meets or exceeds customer expectations. Brand is a vital tool, since the customer can view the identical products with different brands differently. Customer may have the perception on brand based on the past experience of using the brand or the marketing program of each brand, [15]. In addition, brand image is the belief and perception that customers have towards the brand by its properties toward the products or service and which are extrinsic. It also includes the way that the brand is used to meet customers psychological and social needs Thus, a brand equity driver [8]. Moreover, [16] highlight the importance of the brand images on purchase intention. Having a positive brand image, can enhance the customers purchase intention. [8] have proposed "The associative network memory model" where the memory of human brain as a connection between nodes Each node will serve and cache the data as well. As concept and connect the information between nodes in every type of information whether is contextual, abstract or verbal. By the concept of the associative network memory model it can be linked to brand image. Where brand image is the perception of customers towards the brands. Those perceptions that are stored are linked by brand association and other kinds of information that having connection with brain nodes that convey the brand meaning on each customer whether it is on the characteristic of the products, marketers can use that kind of information to generate the set of associations which will vary and will depend on customers and segment, [17] The research of [18] has shown that brand image is linked with the products. Good brand image will result in better brand loyalty and enhance purchase intentions.

Brand Awareness: is the possibility that the customer can recognize, recall, and remember the brand and the firm Investopedia [19]. For promoting the new products, building brand awareness is most important because it enhances the different image of one company's products and services to its competitors. The company that successfully builds brand awareness upon its competitors wil result in high sales and protecting its market share. Presently, there are many ways to build brand awareness, for example, traditional advertising, sponsorship, tie in the product, product placement and social media, [19]. Moreover, [8] suggested in their Customer Based Brand Equity (CBBE) model. that to strengthen loyalty the company must use marketing communication activities by establishing brand awareness by creating positive brand image in the customer memories. As [19] has proposed in his book of "Strategic Brand Management" on how to build the power brand. The Keller's Brand Equity model ideas is that in order to build a robust brand awareness, it is important that the marketers are knowing how the customer thinks and feels of the product. To be successful of building the robust brand, the company should deliver the legitimate types of experience upon the products [19]. Also, [20] has introduced customer centric management framework. A framework that investigates the reasons that drive the customer, and the most important customer values which can divide into 4a: Awareness, Accessibility, Affordability and Acceptability. By taking a close looking towards awareness, we can see that it is the point or boundaries where the customer is facing up with the characteristic of the products and being invited to try or becoming exposed to the product. At this stage the customer will be convince of the use of products or repurchase the products. Brand awareness and product knowledge can be created effectively by advertising and reach potential customers. [21], have stated that by building brand awareness, it will cherish the ability of the customer to remember recall, and recognition of the brand, which will enhance purchasing decision. In addition, it is much easier to build recognition of the brand rather than recall. Furthermore, brand awareness also creates groundwork for brand equity in the future.

Accessibility: [22], defined accessibility as the degree that the customer can simply reach or entered. Applying to automotive industry, accessibility is when the customer can easily reach with the cars dealers and service center. [8], have proposed the idea of Marketing Funnel theory that, in order to build a successful marketing of the products, marketers should become expert in distribution channels such as outlet, internet and should gain accessible to type of media that can reach the target segments through various kind of distribution channel. [23] have mentioned the importance of accessibility since the car purchasing decision is a high involvement process, the majority of purchasers make their car buying decision on the showroom floor. The study of [24] have shown that the car selling process is quite traditional in the past century in which it requires advanced level of personal interaction. Through research many automobile manufacturer, has uncover many sales persons on each car dealership to drive up its sales process. Hence, [24] also support the importance of sales person on the decision-making process by states that the physical facilities of the showrooms equipped with sales people in diving purchase decision and sales force of cars. Moreover, many automotive manufacturers have improved the accessibility by using electronic brochure band electronic product presentation in order to stimulate sales [25].

Price is one of the key influence on product evaluation and purchase decision, many companies employ pricing tactics in order to use pricing to gain market share and customer base. On the consumer psychology and pricing perspective, [8] mentioned about consumer pricing process that the customer usually processes the information about the price based on previous buying experience. In addition, customers have their perceived priced in their minds what will reflect the current price point it should be. However, the perceived price of customers may be different from the price that has been setup by the companies. For example, if the current price is lower than the customer perceived price. Customer may have viewed product as low-quality products or poor-quality produce. However, if the products are price higher than perceived price by customers. It may make customers feels that products are expensive and do not worth to buy [26]. From this reason, pricing is one of the most important factors due to its abilities to influence purchasing decision of the customer. Moreover, it is quite essential for company to know whether the price sensitivity and price elasticity of the target customer [27]. Since the objective of the seller is to charge the highest price in order to gain the highest revenues and profit possible. But, if the price is charge higher than the perceive price, the product could not be sold. To understand this, it is recommending by experts to understand customer willingness to pay. The research of [28] in Thailand has states that price is one of be the main factors that influences purchasing decision. Furthermore, the research has shown that Japanese cars can sold well in Thailand because of their price which is affordable. 
Self Identity: [29], have proposed the research about the social influencers. The authors have mentioned about social identity theory that our global society has various categories of social and social group. At the same time individuals may be in more than one social group. For example, the well grown man can have their role to be the father at home but at the same time this man can be a role of the employees at the company. In the social category, it will contain the element that comes from the culture, norms and the social group as well as the society. Moreover, Social identity is the feeling of belonging that he or she is in the social group. Hence, it also be the part of self-concept. On applying with consumer behavior concept, the customers are often preferring the brands that has reflected the features of their social identity, [30]. Furthermore, the brand can create customer satisfaction and customer preference when it is accomplishing to deliver the personality traits of customer [31]. The further theory of Self-Identity marketing by connecting the brand with the identity also supports this argument by stating that customer may have several identities in the society and often prefers the brand that is accomplished to deliver the attributes that links to their identity [32]. With the research from the scholar like [33], also claim that the individual characteristic of the car purchaser is also having effect on car purchasing decision and the model of the cars that the buyers will choose. On the other hand, if the identity of the products is being match with the customer self-identity it will results in higher satisfaction [10].

\section{Research Framework and Methodology}

Based on the prior literature review that has been discuss earlier. The researcher has come up with seven independent variable which are consists of Attributes, Emotional Connections, Brand Image, Brand Awareness, Accessibility, Price and Self Identity towards one dependent variable which is Purchasing Decision toward ABC's smart automobiles.

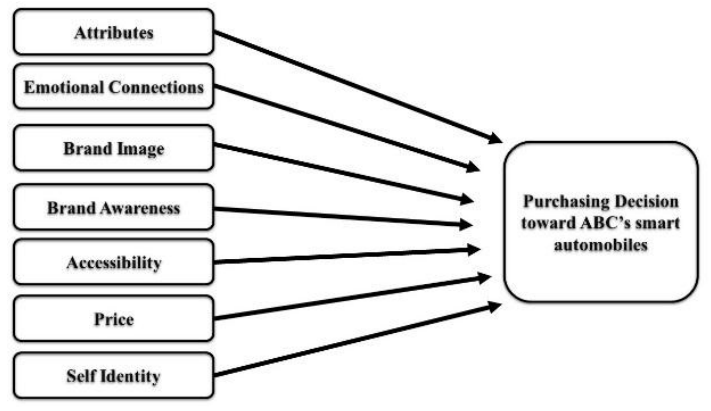

Fig. 1: Conceptual Framework

Adapted From: Narteh, B., Odoom, R., Braimah, M., \& Buame, S. (2012). Key drivers of automobile brand choice in sub-Saharan Africa: the case of Ghana. Journal of Product \& Brand Management, 21(7), 516-528.

This conceptual framework lead to the following seven hypotheses.

H1: Attributes effects purchasing decision of ABC's smart automobiles.

$\mathrm{H}$ 2: Emotional Connections have an effect purchasing decision of $A B C$ 's smart automobiles.

$\mathrm{H} 3$ : Brand Image effects purchasing decision of $A B C$ 's smart automobiles.

H4: Brand Awareness effects purchasing decision of ABC's smart automobiles.

H5: Accessibility effects purchasing decision of ABC's smart automobiles.

H6: Price effects purchasing decision of ABC's smart automobiles.
H7: Self-identity effects purchasing decision of ABC's smart automobiles.

\subsection{Research Methodology}

The researcher has applied the quantitative approach on this study by distributing 385 both physical and online questionnaire as the data collection method. Moreover, the target population are Current $\mathrm{ABC}$ cars owners who is aged more than 18 years old and using their cars in Bangkok Metropolis, Thailand. Meanwhile, the sampling methods that were chosen are Convenience sampling and Judgmental (Purposive) Sampling. On the statistical, the researcher used both descriptive statistics and inferential statistics. On the descriptive statistics percentage, mean and standard deviation are being used. On the inferential statistics. The researcher has applied Multiple Regression (MLR). In addition, the statistical analysis software that are being used is PSPP.

The research questionnaire can be divided into four major parts. Part1: The purpose is to screening the respondent to ensure that the researcher can get the information from the right target respondents which is the dichotomous question. Part 2: Is to gather the demographic information of the respondents. The level of measurement on this part will be used is ordinal and nominal scale. Part 3: is to investigate the ABC's car owner perception of Attributes, Emotional Connections, Brand Image, Brand Awareness, Accessibility, Price and Self-Identity toward ABC's Smart automotive purchasing decision. Thus, the researcher has designed 5-point Likert scale questionnaire in which the respondents will be asked to indicate their level of agreement with a given statement by form of an interval scale. Part 4: The purpose is to investigate by asking the current $\mathrm{ABC}$ cars owner in cases that if $\mathrm{ABC}$ launches the new smart cars to the Thai market, what will be the level of their decision making. As the results, the researcher has designed 5-point Likert scale questionnaire in which the respondents will be asked to indicate their level of agreement with a given statement by the use of interval scale.

\section{Results and Discussion}

\section{Descriptive Analysis}

From the total of 385 respondents, On the perspective of the time frame that the smart car technology will be available in Thai market. Majority of people or $44.16 \%$ are having an idea that smart cars will be available in Thailand market in 5 years or more. Moreover, $23.64 \%$ of the respondents think that it will come to Thailand automotive markets within 4 years. However, $22.60 \%$ of the respondents think that it will takes three years. On the least group of people $9.61 \%$ thinking that it will takes two years for smart cars to come and sell in Thailand automotive market.

Table 1: Model Summary

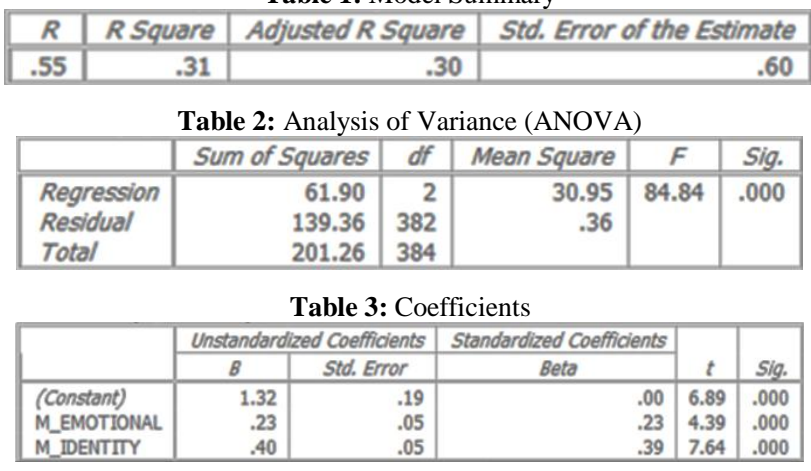

On the inferential statistics, towards seven hypotheses testing, the researcher has applied Multiple Regression (MLR) in the PSPP application. And the outcome would be that there are two alternative hypotheses that were significance on $95 \%$ confidence interval which are composed of Emotional Connection and Self Identity 
which both shown their level of significance of (.000). This means that Emotional Connections have an effect purchasing decision of ABC's smart automobiles. And also, Self-identity effects purchasing decision of ABC's smart automobiles. Self-Identity shows the highest level of affects towards the purchasing decision by having the Standardized Coefficient $\beta$ of .39 followed by Emotional Connection that are having the Standardized Coefficient $\beta$ of .23 .

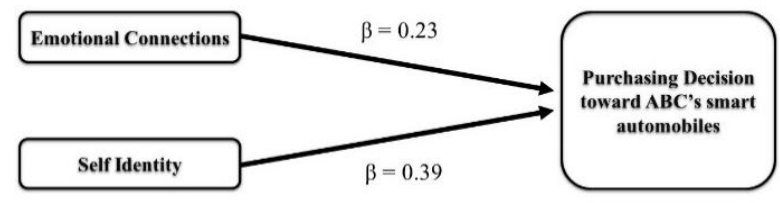

Regression equation $=1.32+0.23$ Emotional Connection +0.39 Self Identity .

Figure 2: Regression Equation

\section{Conclusions, Recommendations and Further Studies}

\subsection{Conclusions}

The researcher has found the factors that influence purchasing decision of ABC's smart cars. Self-Identity shows the highest level of affect to the purchasing decision of $\mathrm{ABC}$ smart cars. Therefore, the theory of social identity states that it will happen when people have a feeling or sense of belonging in the group. The consequence is that the buyer is aiming to buy the smart cars that reflect their personal identity and social status. Therefore, $\mathrm{ABC}$ needs to research \& development, design, manufactured, marketing the products that will be related to the self-identity of their target customers. Because the buyers have the ability to make the decision by themselves. Secondly, on the Emotional Connection. Based on the theory of influential role of emotion in consumer behavior. It states that, emotion is playing an important role in the decision-making process. So, If the company seeks to create the positive feeling on its advertisement, it can influence the buying decision of the smart cars. Hence, ABC should adapt their marketing strategies to be emotion based and Use emotion in order to convince the people to buy Smart cars.

\subsection{Recommendations}

Firstly, since the Adjusted R square is equal to .30, it means that $30 \%$ of the variation in purchasing decision of ABC's smart automobiles can be explained by emotional connection and selfidentity, therefore there are plenty of others factors that have effect on smart cars purchasing decision. So, it would be beneficial for the following research to investigate other factors that having effect on $\mathrm{ABC}$ 's smart cars purchasing decision.

Secondly, based on this research, the researcher has applied Convenience sampling and Judgmental (Purposive) Sampling methods. As the results, target population is not having the equal chance of being selected. Consequently, the researcher suggested that for further research to use Simple Random Sampling methods by reason of the target population will have the equal chance of being selected.

Thirdly, this study is carried out in Bangkok and Metropolitan area. As a consequence, it cannot reflect Thailand as a whole. So, it would be beneficial if the next research will use Thailand as a whole on the area of study, in order to understand the whole picture of smart automotive sectors of Thailand.

\subsection{Further Studies}

Research on Self-identity and Emotional connection: in order to have a very deep understanding of those two variable that are significance, as the topic in the study for the automobile stakeholders. Hence, for the one who are the stakeholder of smart cars or cars enthusiast can understand the model of marketing in order to convey the right messages to the right audience on the target market.

Research on Electronic Vehicles (E.V.).: Smart car technology can be make available on different platform. It can be used incorporate with Internal combustion engine vehicles, Hybrid vehicles, Electric vehicles, and etc. Many well-known company has manufactured their smart cars in the format that uses electric motor as their source of power. This is because in the future, some government will not allow the vehicles that have internal combustion engine to maneuver in the cities due to high carbon-dioxide emission, air and sound pollution. In which the Electric Vehicles will require the car company and related stakeholders to build a new public infrastructure such as charging station. Thus, it may have high initial investment cost in the beginning. Today this type of cars and technology can be seen on the road in the developed countries. With the new electric vehicles technologies, there are more number of gas station that supplies electric charging for electric vehicle and the number of charging station keep on increasingly. In which will generate the new business model of automotive manufacturer and its stakeholder.

Research on other smart technologies (Ex Smart home and smart city): With the era of the internet of things, there are more and more device that can connect to the internet and worked as the integrated system. Smart car alone is the one of the smart technologies that are available to making life easier. With other smart technologies such as city, smart home and etc. Also, (McKinsey \& Company, 2015) has proposed that Smart cars technologies in terms of software and artificial intelligence can be shared with other smart technology. As the new results, the new finding in the related technologies will help creating bigger picture and understanding of the new disruptive technologies.

\section{References}

[1] SAE International (2018), Automated Driving Levels of Driving Automation Defined In New SAE International Standard J3016.

[2] World Health Organization (2015), Global Status Report on Road Safety. Retrieved from: http://www.who.int/violence_injury_prevention/road_safety_status/ 2015/en/ [Accessed 13 Apr. 2018].

[3] Prachachat (2017), ไทยจ่อรั้งอันดับหนึ่งของโลก อุบัติเหตุทางถนนสูญ 4 แสนล้าน !. Retrieved from: https://www.prachachat.net/local-economy/news74655 [Accessed 13 Apr. 2018].

[4] McKinsey \& Company (2015), Ten ways autonomous driving could redefine the automotive world. Retrieved from: https://www.mckinsey.com/industries/automotive-andassembly/our-insights/ten-ways-autonomous-driving-couldredefine-the-automotive-world[Accessed 13 Apr. 2018]

[5] Krungsri Research (2016), Automobile Industry. Retrieved from: https://www.krungsri.com/bank/getmedia/a443d33d-7bf6-4f4db04fb33e04456c34/IO_Automobile_2016_EN.aspx [Accessed 13 Apr. 2018].

[6] Thailand Automotive Institute (2016), ศูนย์สารสนเทศยานยนต์) Automotive Intelligence Unit). Retrieved From:http://data.thaiauto.or.th/iu3/index.php?option=com_flexicont ent $\&$ view=category $\&$ cid=27\&Itemid=65 [Accessed 13 Apr. 2018].

[7] Oxford dictionaries (2018), Definition of attribute in English:. Retrieved from: https://en.oxforddictionaries.com/definition/attribute [Accessed 13 Apr. 2018].

[8] Kotler P, Kevin Lane \& Keller (2016), Marketing Management (15 ed.). England: Pearson Education.

[9] Porter \& Michael (1980), Organizational performance. Academy of Management journal 27(3), 467-488.

[10] Martin LC (1998), Relationship marketing: a high-involvement product attribute approach. Journal of Product \& Brand Management 7(1), 6-26. doi:doi:10.1108/10610429810209700

[11] Kotler P, Kelvin Lane \& Keller (2012), Marketing Management (14 ed.). England: Pearson Education.

[12] Damsio A (1994), 'Descartes' Error: Emotion, Reason, and the Human Brain (1 ed.). New York: Avon Books

[13] Berger J \& Milkman KL (2012), What makes online content viral?. Journal of marketing research 49(2), 192-205. 
[14] American Marketing Association (2018), Dictionary. Retrieved from: https://www.ama.org/resources/Pages/Dictionary.aspx?dLetter=B [Accessed 13 Apr. 2018].

[15] Ferraro R, Kirmani A \& Matherly T (2011), Are They Who They Claim? Intentionality and Authenticity in Identity Signaling With Brands. ACR North American Advances.

[16] Calvo Porral C \& Lang MF (2015), Private labels: The role of manufacturer identification, brand loyalty and image on purchase intention. British Food Journal 117(2), 506-522.

[17] Aaker DA \& Equity MB (1991), Capitalizing on the Value of a Brand Name. New York, 28, 35-37.

[18] Investopedia (2018), Brand Awareness. Retrieved from: https://www.investopedia.com/terms/b/brandawareness.asp [Accessed 13 Apr. 2018].

[19] Keller K (2013), Strategic Brand Management Building, Measuring, and Managing Brand Equity (4 ed.). United States of America: Pearson Education.

[20] Brown SW, Webster Jr FE, Steenkamp JBE, Wilkie WL, Sheth JN, Sisodia,RS \& Bauerly RJ (2005), Marketing renaissance: Opportunities and imperatives for improving marketing thought, practice, and infrastructure. Journal of Marketing 69(4), 1-25.

[21] Percy L \& Rossiter JR (1997), A theory-based approach to pretesting advertising. Measuring advertising effectiveness, 267-281.

[22] Oxford dictionaries (2018), Definition of accessibility in English: Retrieved from: https://en.oxforddictionaries.com/definition/accessibility [Accessed 13 Apr. 2018].

[23] Raphael N, Mahama O, \& Samuel B (2012), Key drivers of automobile brand choice in sub-Saharan Africa: the case of Ghana Journal of Product \& Brand Management 21(7), 516-528. doi:doi:10.1108/10610421211276268

[24] West TP \& Saker J (2012), Computer assisted sales processes in automotive retailing. International Journal of Retail \& Distribution Management 40(7), 493-509. doi:doi:10.1108/09590551211239828

[25] Reed G, Story V \& Saker J (2004), Information technology: changing the face of automotive retailing? International Journal of Retail \& Distribution Management 32(1), 19-32. doi:doi:10.1108/09590550410515524

[26] Central European Conference on Information and Intelligent Systems (2018), The influence of price on customer's purchase decision. Retrieved from http://archive.ceciis.foi.hr/app/public/conferences/1/ceciis2015/pap ers/754.pdf [Accessed 14 Apr. 2018]

[27] Manika R, Sabine P \& Ulrich H (2016), Organic consumers' price knowledge, willingness-to-pay and purchase decision. British Food Journal 118(11), 2732-2743. doi:doi:10.1108/BFJ-04-2016-0164

[28] Thanasuta K, Patoomsuwan T, Vanvisa C \& Chaimahawong Y (2009) ,Brand and country of origin valuations of automobiles. Asia Pacific Journal of Marketing and Logistics 21(3), 355-375. doi:doi:10.1108/13555850910973847

[29] Langner S, Hennigs N \& Wiedmann KP (2013), Social persuasion: targeting social identities through social influencers. Journal of Consumer Marketing 30(1), 31-49.

[30] Forehand MR, Deshpandé R \& Reed II (2002), Identity salience and the influence of differential activation of the social self-schema on advertising response. Journal of Applied psychology 87(6), 1086

[31] Govers PCM, \& Schoormans JPL (2005), Product personality and its influence on consumer preference. Journal of Consumer Marketing 22(4), 189-197. doi:doi:10.1108/07363760510605308

[32] Ghosh Chowdhury T, Desai KK \& Bolton L (2014), Accentuate the positive: how identity affects customer satisfaction. Journal of Consumer Marketing 31(5), 371-379.

[33] Prieto M \& Caemmerer B (2013), An exploration of factors influencing car purchasing decisions. International Journal of Retail \& Distribution Management 41(10), 738-764. doi:doi:10.1108/IJRDM-02-2012-0017 